\title{
Vertical Distribution of Root Lesion Nematode (Pratylenchus thornei) under Chickpea- Maize Crop Rotation
}

\author{
Rajbabbar Jatav*, S.P. Tiwari and Balkishan Chaudhary \\ Department of Plant Pathology, JNKVV, Jabalpur (M.P.) 482004, India \\ *Corresponding author
}

\begin{abstract}
A B S T R A C T
Root lesion nematode; Pratylenchus thornei (Sher and Allen) is a migratory endoparasite

\begin{tabular}{|c|}
\hline Keywords \\
\hline $\begin{array}{l}\text { Root Lesion } \\
\text { Nematode, } \\
\text { Chickpea and } \\
\text { Maize }\end{array}$ \\
\hline Article Info \\
\hline $\begin{array}{l}\text { Accepted: } \\
20 \text { December } 2019 \\
\text { Available Online: } \\
\text { 10 January } 2019\end{array}$ \\
\hline
\end{tabular}
commonly fed and reproduced in the cortical tissue of the host. Necrotic lesions are developed when they commonly severe infesting the host roots. To determine the their vertical distribution of in chickpea - maize crop rotation, the soil and root samples were collected from different levels of soil depth during Rabi-2016 and Kharif-2017. The size of sample was $1 \mathrm{~kg} / \mathrm{depth}$ and replicated thrice. The samples were processed with Whitehead tray extraction method and $P$. thornei populations were examined. Distribution of $P$. thornei in chickpea field was enormous and they were between 4.5 to $30 \mathrm{~cm}$ of the soil depth with the encountered population ranging from 600 to $5000 \mathrm{~N} / 200 \mathrm{~cm}^{3}$ soil and 100 to $700 \mathrm{~N} / 5 \mathrm{~g}$ root. The samples collected from rhizospheric soils of maize kharif were examined for their distribution pattern, was maximum (1000-1200 N/200 $\mathrm{cm}^{3}$ soil) between 12 to $18 \mathrm{~cm}$ soil depth. However depth of $10 \mathrm{~cm}$ was encountered with ambient population of nematodes whereas $16 \mathrm{~cm}$ there was scarcity of the population. Simultaneously examination of the maize roots population around the maize was not sustained in any of the roots within different depth of soil.
\end{abstract}

\section{Introduction}

The Pratylenchus thornei have been reported one of the biotic stress which mainly rechangable for yield losses to the tube of 40 $\%$ in intolerant cereals and legumes in South Australia (Nicol, 1996). Reliable and right sampling for plant-parasitic nematodes is essential to determine relative densities of population correlated with the yield losses in presence of nematode density and which could help to reason assessment for management strategies. The sampling of vertical distribution of $P$. thornei will differ with existing conditions and unfavorable reason (Boag et al., 1987; Boag et al., 1992). Horizontal distribution of plant-parasitic nematodes is affected by the distribution pattern namely the root systems (Kimpinski and Welch, 1971), but also governed by edaphic factors nearly rhizosphere such as temperatures, soil types and $\mathrm{pH}$ (Wallace et al., 1993; Sarah et al., 1991). Vertical distribution of nematodes in soil confined with different nematode species (Davis et al., 1994), distribution of the host's root systems (Mac Guidwin and Stanger 1991; Rawsthorne and Brodie, 1986) and the soil type which 
differed environmental conditions (Ferris and Mc Kenry, 1974; Sohlenius and Sandor, 1987). Most of the studies during past suggested nematode densities in the top 15-20 $\mathrm{cm}$ soil profile and it appear to be the optimum sampling depth (McSorley and Dickson, 1990). In the black clay vertisols of the Queensland, the majority of RLN are presence between 15 and $60 \mathrm{~cm}$ but they can even present to the depths of $90 \mathrm{~cm}$ (Thompson, 1990). Another factor which may be considered while assessing sampling techniques provides distribution of nematode and their recovery. Mechanical disturbance during cultivation could reduce recovery of Pratylenchus spp. (McSorley and Gallaher, 1993) and soil sampling result disturbance similar to that of tillage. This effect is likely to be greatest when nematodes have survived within extended dry periods in a state of anhydrobiosis (Hinton, 1968). In the northern hemisphere, $P$. thornei has been reported frequently anhydrobiosis (Glazer and Orion 1983; Tobar et al., 1996) whereas, in South Australia, high numbers of both $P$. thornei and $P$. neglectus recovered with great number in soil and coiled in dry cereal roots during summer. The aim of the studies was confirms the distribution of $P$. thornei in the different soil depth or their vertical density in chickpea- maize crop alternations.

\section{Materials and Methods}

Study sites were located in BISA Jabalpur (M.P.) and collected samples were transported to store before and assess of population in the Department of Plant Pathology, JNKVV, Jabalpur (M.P.). Soil samples were collected before cultivation and sowing of cereal or legume crops from June-July and OctoberNovember. Identification of Pratylenchus species was based on vulval position of: $P$. thornei $\mathrm{V}=73-80 \%$ (Loaf, 1991) of the sample $200 \mathrm{~cm}^{3}$ and $5 \mathrm{~g}$ roots were processed for the nematode extraction with Whitehead tray method (Whitehead and Hemming,
1965). Soil samples were collected with the help of soil auger sampler from the 4.5, 8, 12, 16,20 , and $30 \mathrm{~cm}$ depth of soil. Samples were taken after the harvest of the each crops viz. chickpea (March) and Maize (October).

\section{Analysis}

All data were analyses on the bases of distribution of nematodes at different depth were expressed as percentage of total nematode (McSorley and Dickson, 1990).

\section{Results and Discussion}

\section{Vertical distribution}

Data evidenced from Table 1 showed maximum and significant $(\mathrm{P}=0.05)$ nematode populations within $12-16 \mathrm{~cm}$ depth with the population of $5084 \mathrm{~N} / 200 \mathrm{~cm}^{3}$ soil depth in chickpea whereas between 8-12 cm encountered population $4045 \mathrm{~N} / 200 \mathrm{~cm}^{3}$ soil from chickpea; whereas from maize nematode populations was drastically reduced and the minimum populations were found in between 20-30 was $55.33 \mathrm{~N} / \mathrm{cm}^{3}$ soil. However population above threshold level of damage were predominant within $12-30 \mathrm{~cm}$ of soil depth in chickpea whereas $4-12 \mathrm{~cm}$ in maize.

Nematodes were recovered from the all the six soil depth during the investigation from both crops. The maximum (89.86 \%) (Table 2) of nematodes population was recovered up to the $20 \mathrm{~cm}$ of the soil depth in chickpea cultivation whereas poor in the maize but it was maximum $(91.76 \%)$ up to $12 \mathrm{~cm}$ soil depth.

\section{Reproduction factor}

The maximum reproduction of $P$. thornei was at 8-12 and 12-16 cm depth was significantly increased the nematode population during chickpea (Table 3). 
Table.1 Vertical distribution of Pratylenchus thornei in the six different soil profiles

\begin{tabular}{|c|c|c|c|c|}
\hline \multirow{2}{*}{$\begin{array}{c}\text { Soil depth } \\
\text { (cm) }\end{array}$} & $\begin{array}{c}|c| \\
\text { Nematode } \\
\text { population/5g } \\
\text { root }\end{array}$ & $\begin{array}{c}\text { Nematode } \\
\text { population /200 } \\
\mathbf{c m}^{\mathbf{3}} \text { soil }\end{array}$ & $\begin{array}{c}\text { Nematode } \\
\text { population/ 5g } \\
\text { root }\end{array}$ & $\begin{array}{c}\text { Nematode } \\
\text { population/200 } \\
\mathbf{c m}^{3} \text { soil }\end{array}$ \\
\hline $\mathbf{0 - 4}$ & 101.67 & 616.33 & - & 346.33 \\
\hline $\mathbf{4 - 8}$ & 215.00 & 1842.00 & - & 750.00 \\
\hline $\mathbf{8 - 1 2}$ & 510.33 & 4045.00 & - & 1211.00 \\
\hline $\mathbf{1 2 - 1 6}$ & 728.67 & 5084.00 & - & 86.67 \\
\hline $\mathbf{1 6 - 2 0}$ & 115.00 & 3160.33 & - & 65.00 \\
\hline $\mathbf{2 0 - 3 0}$ & 63.33 & 1790.00 & - & 55.33 \\
\hline CD at 5\% & $\mathbf{7 9 . 3 7 4}$ & $\mathbf{3 9 8 . 2 5 4}$ & - & $\mathbf{5 1 . 6 8 2}$ \\
\hline
\end{tabular}

Table.2 Per cent distribution of nematode population in different six soil depth

\begin{tabular}{|c|c|c|}
\hline \multirow{2}{*}{$\begin{array}{c}\text { Soil depth } \\
(\mathbf{c m})\end{array}$} & Chickpea & Maize \\
\cline { 2 - 3 } & Percent Nematode Population & Percent Nematode Population \\
\hline $\mathbf{0 - 4}$ & 3.93 & 13.77 \\
\hline $\mathbf{4 - 8}$ & 11.26 & 29.83 \\
\hline $\mathbf{8 - 1 2}$ & 24.93 & 48.16 \\
\hline $\mathbf{1 2 - 1 6}$ & 31.81 & 3.45 \\
\hline $\mathbf{1 6 - 2 0}$ & 17.93 & 2.59 \\
\hline $\mathbf{2 0 - 3 0}$ & 10.14 & 2.20 \\
\hline
\end{tabular}

Significant at CD (0.05) level of significance

Table.3 Reproduction factor of Pratylenchus thornei in six different soil depth levels during chickpea

\begin{tabular}{|c|c|c|c|}
\hline $\begin{array}{c}\text { Soil Depth } \\
\text { (Cm) }\end{array}$ & $\begin{array}{c}\text { Initial Nematode } \\
\text { Population (before sowing) }\end{array}$ & $\begin{array}{c}\text { Final Nematode } \\
\text { Population (after harvest) }\end{array}$ & $\begin{array}{c}\text { Reproduction } \\
\text { Factor (Pf/Pi) }\end{array}$ \\
\hline $\mathbf{0 - 4}$ & 264.67 & 718.00 & 2.71 \\
\hline $\mathbf{4 - 8}$ & 450.00 & 2057.00 & 4.47 \\
\hline $\mathbf{8 - 1 2}$ & 876.00 & 4555.33 & 5.20 \\
\hline $\mathbf{1 2 - 1 6}$ & 1142.00 & 5812.67 & 5.08 \\
\hline $\mathbf{1 6 - 2 0}$ & 1040.67 & 3275.33 & 3.15 \\
\hline $\mathbf{2 0 - 2 2}$ & 646.67 & 1853.33 & 2.87 \\
\hline
\end{tabular}

Nematode population were significant at $\mathrm{CD}=5 \%$ level of significance

Maximum Pratylenchus spp. population was predominantly up to in the top $16 \mathrm{~cm}$ and was $89.86 \%$. The deeper depth of soil, hold
Pratylenchus thornei whereas quit low within a depth of $0-8 \mathrm{~cm}$. Although higher nematodes levels in shallower soil layers are 
consistent and high from deeper depth (McSorley, 1987; MacGuidwin and Stanger, 1991). In South Australian soils, vertical distribution of nematodes probably reflects root distribution as most plant root growth was concentrated in the upper $20 \mathrm{~cm}$ of the soil depth. In deep soil, Pratylenchus thornei were detected even at the greatest depth sampled $(120 \mathrm{~cm})$ as previously reported in Australia (Davis et al., 1994). Most of the previous studies reported maximum nematode densities in the top $15-20 \mathrm{~cm}$ of the soil profile and this appears to be the most common sampling depth (McSorley and Dickson, 1990). The nematodes population was decreased when crop sequenced with the non host crop maize then chickpea accord with McSorley and Dickson (1990); Davis et al., (1994) Barley is an effective rotation crop in Pratylenchus-infested soil due to its greater tolerance and resistance to $P$. thornei and $P$. neglectus. The reproduction factors with maximum population were noticed up to the $16 \mathrm{~cm}$ of the soil depth.

\section{Acknowledgements}

I wish to thanks Dr. Pankaj Singh (Station Incharge) and Manish Vishwakarma (Breeder) and Uttam Kumar (Scientist), BISA Farm, Jabalpur (M.P.) who provide the facilities to work take this investigation.

\section{References}

Boag B., Brown D.J.F., and Topham P.B. (1987). Vertical and horizontal distribution of virus-vector nematodes and implications for sampling procedures. Nematologica 33: 83-96.

Boag B., Neilson R. and Brown D.J.F. (1992) Seminar: Nematode sampling and precision. Nematologica 38: 459-465.

Davis R.F., Wilkinson H.T. and Noel G.R. (1994) Vertical distribution of three nematode genera in a Bentgrass putting green in central Illinois. Journal of Nematology 26: 518-521.

Ferris H. and McKenry M.V. (1974) Seasonal fluctuations in the spatial distribution of nematode populations in a Californian vineyard. Journal of Nematology 6: 203-210.

Glazer I. and Orion D. (1983). Studies on anhydrobiosis of Pratylenchus thomei. Journal of Nematology 15: 333-338.

Hinton H.E. (1968). Reversible suspension of metabolism and the origin of life. Proceedings of the Royal Society of London 171: 43-57.

Kimpinski J. and Welch H.E. (1971). The biology of nematodes in Manitoba soils. Nematologica 17: 308- 318.

MacGuidwin A. E. and Stanger B. (1991). Changes in the vertical distribution of Pratylenchus scribnevi under potato and corn. Journal of Nematology 23:73-81.

McSorley R and Gallaher R.N. (1993). Effect of crop rotation and tillage on nematode densities in tropical corn. Journal of Nematology (Supp) 25(4S): 814-819.

McSorley R. (1987). Plot size and design for acquisition of fields data in nematology. In Vistas on Nematology (Eds 1A. Veech and D.W. Dickson), pp. 52-58. Society of Nematologists, Hyattsville.

McSorley R. and Dickson D.W. (1990). Vertical distribution of plant-parasitic nematodes in sandy soil under maize. Plant and Soil 123: 95-100.

Nicol J.M. (1996). The distribution, pathogenicity and population dynamics of Pratylenchus thornei on wheat in South Australia. PhD Thesis, Department of Crop Protection, University of Adelaide, South Australia.

Rawsthorne D. and Brodie B.B. (1986). Relationship between root growth of potato, root diffuse at production, and hatching of Globodera rostochiensis. Journal of Nematology 18: 379-384.

Sarah J.L., Osseni B. and Hugon R. (1991). 
Effect of soil $\mathrm{pH}$ on development of Pratylenchus brachyurus populations in pineapple roots. Nematropica 21: 211216.

Sohlenius B. and Sandor A. (1987). Vertical distribution of nematodes in arable soil under grass (Festuca pratensis) and barley (Hordeum disticum). Biology and Fertility of Soils 3: 19-25.

Thompson J.P. (1990). Treatments to eliminate root lesion nematode (Pratylenchus thomei Sher \& Allen) from a vertisol. Nematologica 36: 123127.

Tobar A., Valor H. and Talavera M. (1996).

On the field anhydrobiotic ability of
Pratylenchus thornei and Merlinius brevidens. Fundamental of Applied Nematology 19 (1): 43-46.

Wallace M. K., Rust R. H., Hawkins D. M. and MacDonald D. H. (1993). Correlation of edaphic factors with plant-parasitic nematode population densities in a forage field. Journal of Nematology 25(4): 642-653.

Whitehead A. G. and Hemming J. R. (1965). A comparison of some quantitative methods of extracting small vermiform nematodes from soil. Ann. Appl. Biol. 55:25-38.

\section{How to cite this article:}

Rajbabbar Jatav, S.P. Tiwari and Balkishan Chaudhary. 2019. Vertical Distribution of Root Lesion Nematode (Pratylenchus thornei) under Chickpea- Maize Crop Rotation. Int.J.Curr.Microbiol.App.Sci. 8(01): 2883-2887. doi: https://doi.org/10.20546/ijcmas.2019.801.305 